\title{
Professor Volodymyr Zemskov a world-renowned Ukrainian surgeon
}

The article describes the professional and scientific way of professor Volodymyr Serhiyovych Zemskov, a prominent Ukrainian surgeon and a founder of the Kyiv Center for Liver, Bile Ducts and Pancreas Surgery which is currently based in the Kyiv City Clinical Hospital No10. The article presents the memories of his students and contemporaries, the facts about his professional biography and career development. The paper describes the main scientific interests of Volodymyr Zemskov, his achievements and scientific work.

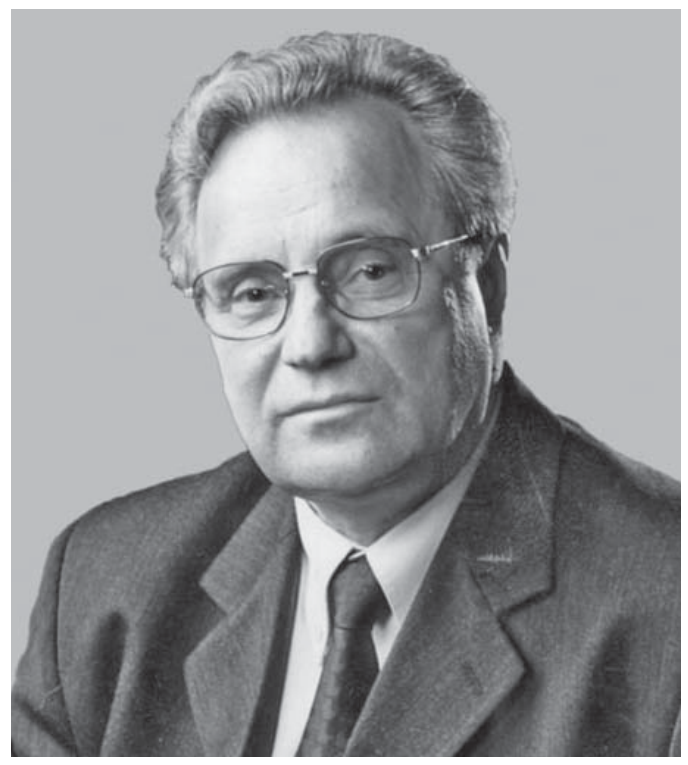

Acute pancreatitis is one of the most dangerous urgent surgical pathologies. Even at present, in the era of high-tech diagnostic equipment, methods of low-traumatic surgical interventions, availability of various pharmaceutical products, acute pancreatitis and other conditions of hepato-pancreatobiliary area contribute to high mortality among the working age population. It is considered that the surgeons, who perform upper abdominal surgeries, master the art of surgery meticulously and the specialists, who carry out urgent surgical interventions in this anatomical area must be ready to demonstrate their skills around the clock. That is, 24 hours a day and 7 days a week. Such work schedule is routine for the Kyiv Center for Liver, Bile Ducts and Pancreas Surgery which functions in the Kyiv City Clinical Hospital No10. It's difficult to count the number of lives that were saved thanks to the surgeons of the Center and the number of patients that were cured by them. The establishment of the Center became possible by virtue of one person, professor Volodymyr Zemskov, famous for his high professionalism and organizational talent. And nowadays, the functioning of this institution plays a crucial role in the health care system of the capital.

In 1982, professor Zemskov initiated the establishment of the Center at Oleksandrivska clinical hospital, one of the oldest hospitals in Kyiv. At that time, the hospital had at its own disposal 1200 beds. The Center was placed in the surgical corps which was almost 100 years old. Neither the absence of proper financial support and technical conditions nor a large flow of patients with severe urgent medical conditions didn't make professor refuse from setting up the Center. In Volodymyr Zemskov's official personal file, which is kept in the archives as the file of the official member of Kyiv medical institute, is noted that from 1982 to 1987 «...the Center provided more than 30000 Kyiv residents, the population of the republic as well as foreign citizens with specialized medical assistance, including surgery, hospital treatment and consultations. Professor Zemskov performs about 300 operations annually to manage the most difficult to treat conditions of the liver, biliary tract, pancreatic gland and other organs...». In 1989, the Center was temporarily relocated to Kyiv City Clinical Hospital No10 because of the reconstruction of Oleksandrivska clinical hospital. It is, however, well known that nothing lasts longer than the temporary, so the Center functions in this medical facility even today.

Before the establishment of the Center, professor Zemskov walked a bright but thorny path in surgery. He graduated from Luhansk (at that time - Voroshilovgrad) Medical Institute in 1962. Years later, professor reminisced about his Alma Mater: «Luhansk Medical Institute was absolutely groundbreaking with excellent teachers. There was a wide range of things 
that were allowed for us as for students: a lot of attention was focused on practice sessions, there functioned special leading-edges of all the main disciplines. I took part in the operations in the first year of medical studies. At first, of course, on dogs (by the way, since that time I've been against experiments on dogs, I like them so much). In the second or third course of my medical education I definitely knew that medicine is my way in life...». An ability to model and take part in experimental surgery influenced future professional progress of Volodymyr Zemskov. Oleksandr Shalimov discovered his talents and invited Zemskov to work for the Institute that he ran.

Before his meeting with Shalimov, Volodymyr Zemskov had worked in oncology dispensaries in Perevalne and Alchevsk for about 10 years. During that period, his working day lasted 18 hours and he performed over 100 surgical interventions including the most difficult ones.

He considered Pavlo Kravtsov, who was a surgeon and a chief of the dispensary, his first teacherclinician. In 1969, after four unsuccessful attempts to enter the doctoral program in Moscow and Kyiv, he finally became a postgraduate student at Kyiv Research Radiological-Oncological Institute, where in a twist of fate he met Ivan Shevchenko a leading scientist and a founder of the Institute. In 1972, Volodymyr Zemskov got his PhD degree under Ivan Shevchenko's leadership. The theme of his dissertation research was $\ll \mathrm{A}$ comprehensive diagnostics of malignant melanoma of the skin».

Then Oleksandr Shalimov noticed a talented and forward-looking PhD-surgeon. In 1973, Volodymyr Zemskov obtained a position of a junior research fellow in the department of experimental surgery. Later Volodymyr Zemskov started working at the department of liver, biliary tract and pancreatic surgery, since 1979 - as a senior researcher and a head of the department. At that time, Volodymyr Zemskov worked hard for sanitary aviation, providing special surgical assistance in the farthest outlying towns in most of the republics of the former USSR. Volodymyr Zemskov acquired valuable practical and organizational experience working under the leadership of Oleksandr Shalimov and it eventually helped him establish the Center and the Department of General Surgery of Kyiv Medical Institute. Professor Zemskov said about Oleksandr Shalimov: «I learned many things from Shalimov: in terms of both organizational qualities and the skills which are required for surgical practice and scientific activity».

In 1981, Volodymyr Zemskov obtained a Doctor of Medicine degree with the research «Surgical treatment of acute pancreatitis and its complications» and in the same year he took up the position of the chief of one of the oldest departments of Kyiv Medical Institute - the Department of General Surgery. This department was established in 1889. It developed under the leadership of such famous surgeons as Oleksandr Pavlovsky, Mykhailo Diterihs, Ivan Zavyalov and others.

Professor Zemskov knew how to reconcile surgical practice with teaching and scientific work. In 1982, he established the Kyiv Center for Liver, Bile Ducts and Pancreas Surgery where he spent most of his time.

In 1985, Volodymyr Zemskov was the first ever incumbent of Kyiv Medical Institute who received the State Prize of the USSR. He became a laureate of such an honorable award for «The development and clinical implementation of methods and techniques of cryodestruction of malignant tumours». In 1987, he was elected a member of the International Association of Hepatobiliary Surgery. In 1988, professor Zemskov received the title of the Distinguished figure of science of the USSR.

One of his most significant merits is his surgery school. During his career Volodymyr Zemskov was a teacher for many young surgeons who became professors and the heads of the department later. Today, his disciple, professor Yaroslav Susak is the head of the department of surgery with the course of emergency and vascular surgery at Bogomolets National Medical University. Professor Volodymyr Skyba is chaired by the department of surgery, anesthesiology and intensive therapy of postgraduate education at the same university. Professor Vasyl Khrapach leads the department of plastic and reconstructive surgery of postgraduate education at Bogomolets National Medical University.

«There are surgeons who can operate perfectly, create a school to teach doctors and capture them with their ideas and lead people. This is exactly about my teacher Volodymyr Zemskov...» - that's how surgeon Yuryi Lifshyts said about his teacher and added: «He belongs to those people who work pushing themselves to the limit. His manner of life was very close to Vysotskyi. He read a lot, he knew everything. A high intelligence. Shalimov developed and realized the most difficult researches with Zemskov. For example, treatment of purulent pancreatitis. The mortality caused by this condition in 1970s was about 70\%. Zemskov implemented a technique which allowed to reduce it and defended his doctoral dissertation. He looked after literally every patient after the operation by himself».

Professor Zemskov, despite his status, personally participated in the rehabilitation of his patients. He was an extremely sensitive doctor. Not only a surgeon, but also a psychologist for his patients. Volodymyr Zemskov said: «Unfortunately, death is 


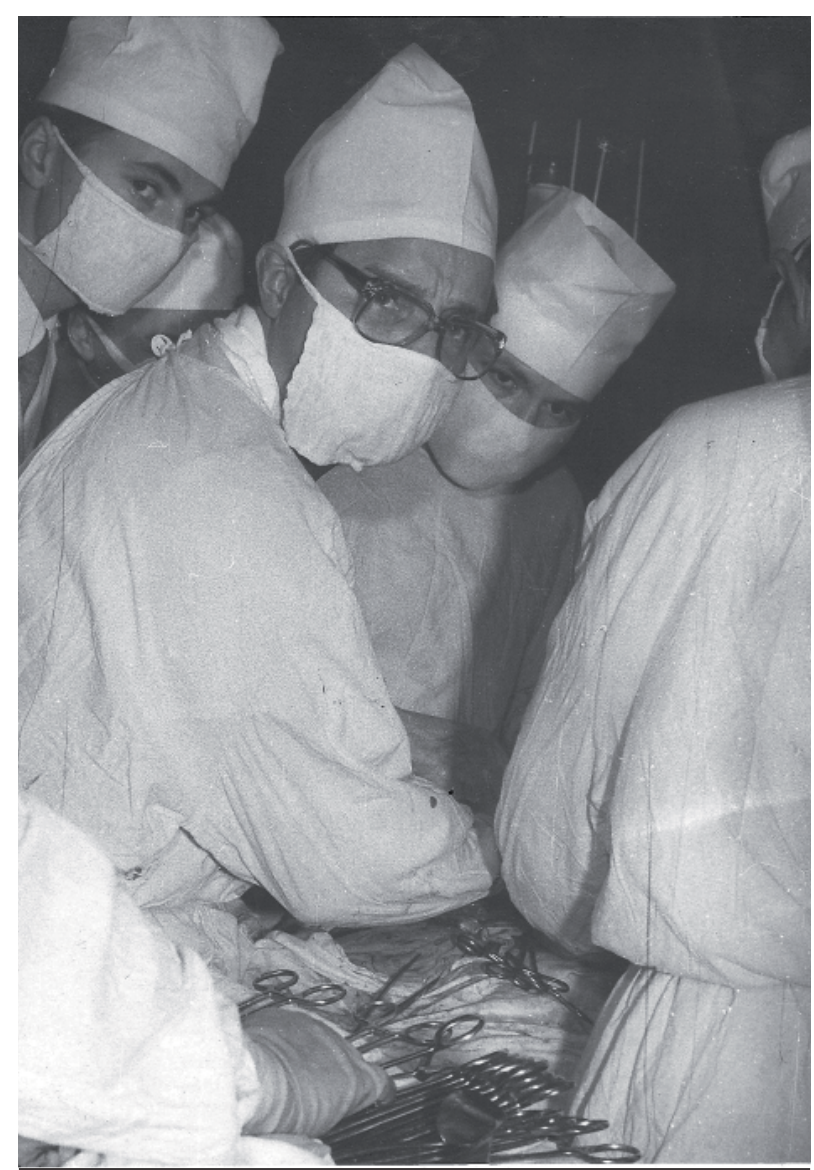

In the center - Volodymyr Zemskov, mid-1970s

inevitable, no matter how hard you fight it. But it's scary when there is an opportunity to save a person, and it is not used because of someone's stupidity and laziness. This is a big sin. Sometimes, according to all prognoses, a person must die, and they still survive. Or vice versa: the operation was successful, the wounds heal quickly, but the disease suddenly progresses again. I believe that recovery depends on both the psychological state and the soul, the presence of the spiritual in a person, something that we cannot fully understand...».

Of course, this pace and intensity of work influenced Professor Zemskov. He finds relief from chronic fatigue and regular stress at home, with his family. Professor Zemskov greatly appreciated the time he spent with his beloved wife and children who also became doctors in the future. «Family and home are extremely important. My wife is also a doctor, we met at the institute, it was love at first sight. We have been together for more than 30 years since then. When you come after a hard shift, after many hours of operations, it is just necessary that the family supports you, listens, understands... "the professor said to his students.

In 1995, Volodymyr Zemskov was awarded the title of Academician of the Universal Academy Guglielmo Marconi (Rome, Italy) for his medical research in the field of cancer. He was elected a member of the European Order of Dignity A.S. O.E. M. (Brussels, Belgium) and the Albert Schweizer Society (Austria), as well as many other international charitable non-profit organizations. In 1997, he was elected a member of the International Surgical Society (ISS).

During the 90s, the professor continued to run the department and the Center. He began to develop the newest, at that time, direction - endovideoscopic surgery and to introduce it into the practice of treatment of acute surgical diseases of the hepato-pancreato-biliary zone. He continued to spend most of his time at work and in the best traditions of medical self-sacrificing humanism «burned himself while shining a bright light on others». One of his numerous students, Professor Inna Kovalska, recalled: «Even if other doctors abandoned the patient, believing that it was impossible to save him, Zemskov operated. Here is a vivid example: a 16-year-old girl who was diagnosed with a malignant tumor of the pancreas which was estimated as inoperable by the different surgeons, but Volodymyr Zemskov removed her tumor and prescribed a course of treatment. The girl survived. The professor always said: «It is not for us to judge how many days, months, years a person is allowed, the task of a doctor is to make this time not a continuous torment, but a real life...».

During his life, Professor Zemskov was the author of more than 500 scientific papers, 5 monographs, 45 inventions and patents.

In 2002, a year before the 30th anniversary as the head of the Department of General Surgery, Volodymyr Zemskov died of myocardial infarction at the age of 61. In 2009, a granite memorial plaque, commemorating Volodymyr Zemskov, was erected at the surgical building of the Kyiv City Clinical Hospital No10, where the Center established by the professor continues to function. His name is forever engraved in the history of national surgery.

\section{Y. Susak, S. Zemskov, D. Dubenko}

Bogomolets National Medical University, Kyiv 


\section{Професор Володимир Земсков - всесвітньовідомий український хірург}

\section{Я. Сусак, С. Земсков, Д. Дубенко}

Національний медичний університет імені О. О. Богомольця, Київ

У статті представлено професійний та науковий шлях професора Володимира Сергійовича Земскова видатного українського хірурга, засновника Київського центру хірургії печінки, жовчовивідних шляхів та підшлункової залози, який сьогодні функціонує на базі Київської міської клінічної лікарні № 10. Наведено спогади учнів та сучасників, факти щодо професійної біографії та кар'єрного становлення. Також описано основні наукові інтереси Володимира Земскова, його здобутки та наукові роботи. 